\title{
THE 1842 “PLUG PLOT” IN STOCKPORT*
}

The origins and nature of the strike movement which affected the manufacturing districts of England during the summer of 1842 have been subject to a variety of interpretations. The very use of the term "Plug Plot" suggests some sinister motivation, and certainly belief in the existence of a conspiracy became widespread as the strike proceeded. According to the Manchester Guardian

Those who look upon this outbreak as a mere turn-out for wages, - an attempt to resist a reduction of a half-penny per piece in weaving calico; and who suppose that it might be brought to a termination by acceding to the present demand, or to any demand for an advance in wages, - fall into a mistake, which is not only great, but exceedingly dangerous. What is now taking place has not come upon us by surprise. We know that it has been agitated for several months past; that it has formed the subject of discussion at the chartist Sunday meetings which have been held in many parts of the district; and that it is, in fact, the carrying-out of that fiendish scheme developed by Mr. FEARgus O'ConNor and other agitators, so long ago as October, 1838, under the name of the "sacred week," and the "national holiday;". ${ }^{1}$

On the same day, O'Connor in the Northern Star offered another view.

Every post brings us additional confirmation that the anti-Corn Law League are at the bottom of all the proceedings connected with the STRIKE.

He then proceeded to issue the following warning:

* We are indebted to Professor John Saville, who read an earlier draft of this article, and provided many helpful comments. All dates cited refer to the year 1842 , unless otherwise specified.

1 Manchester Guardian, 13 August. 
Chartists, beware! Be not mixed up with these proceedings! Keep Chartism distinct from the "risings" and the "riotings"! Give your enemies no hold of you; and suffer them not to USE you, and then coerce you!'

Those who have studied the "Plug Plot" in retrospect have tended to discount such conspiracy theories, and view events in the light of economic conditions; the demand for higher wages and, in some cases, for the abolition of the "truck" system. The strikes are seen as a spontaneous protest movement ${ }^{3}$ or, at most, a technique of primitive collective bargaining, ${ }^{4}$ which the Chartists, and some individual members of the AntiCorn-Law League, ${ }^{5}$ attempted to exploit for their own ends. The "Plug Plot", however, proved beneficial to none of the various groups. The mass of operatives, more impoverished than when they had turned out, resumed work at the pre-strike wage rates. The Chartists, whom the authorities generally considered to be the instigators of the disturbances, witnessed the trial and imprisonment of many of their leading members. The AntiCorn-Law League emerged from the episode in an aura of suspicion and recriminations. ${ }^{6}$

Yet the "Plug Plot" cannot be dismissed simply as an outbreak which, although it occasioned much public disorder and private suffering, ended simply in a return to the social and economic status quo. The strike situation immediately brought to the fore the fundamental dilemma: whether the working class should concentrate upon demands for far-reaching political changes, or simply attempt to achieve more immediate improvements in social and economic conditions by means of collective bargaining. Despite the attempt by some Chartists to unite the political with the industrial struggle, the strike served only to polarize the two camps, and it may be argued that from 1842 , rather than from 1848, began the hegemony of trade unionism over working-class political action. Nor was that hegemony short-lived; it continued unabated until the formation of the Independent Labour Party.

2 Northern Star, 13 August.

3 For example, see D. Read, "Chartism in Manchester", in: Chartist Studies, ed. by Asa Briggs (London, 1959), p. 54; H. Pelling, A History of British Trade Unionism (Harmondsworth, 1963), p. 43; J. T. Ward, Chartism (London, 1973), pp. 162-63.

4 E. J. Hobsbawm, "The Machine Breakers", in: Labouring Men (London, 1964), pp. 8-10, 19, note.

5 "Anti-Corn-Law Agitation", in: Quarterly Review, LXXI (1842), passim. This article attempts to place responsibility for the strike upon the League. It also describes the activities of some individual members, including George Southam of Ashton.

6 Ward, Chartism, op. cit., pp. 164-65. 
The strikes eventually affected parts of Lancashire, Cheshire, Yorkshire, Staffordshire, the Potteries, Warwickshire, and even South Wales. ${ }^{7}$ They were never co-ordinated on a national or even regional level, thus the term "general strike", with its twentieth-century overtones of central organization and management, cannot accurately be applied to the situation of 1842. The pattern tended to be for strikers from individual mills or factories to turn out other operatives in their district, and for groups then to proceed to neighbouring towns, to further the strike movement there. Thus in order to examine the relative importance of political and trade-unionist motives in the course of the strike, it is necessary to consider a limited local area in some detail, rather than to attempt to map the movements of strikers throughout the whole of the districts affected. This analysis will therefore concentrate upon events in the town of Stockport, while at the same time attempting to place the local strike movement within the context of activities in the surrounding area: the Hyde-Ashton-Stalybridge district, Manchester, and adjacent parts of Cheshire.

Stockport could by no means claim to be the instigator of the strike movement in that locality, or even its hub, but the town does present certain interesting features. It was one of the principal cotton-manufacturing towns in the country and could, largely as a result of its early industrialization, boast a long tradition of working-class political and trade-union activity. ${ }^{8}$ The local Chartist movement, which could trace its origins to Feargus O'Connor's visit in December $1835,{ }^{9}$ had, from its inception, taken up the leadership of local working-class agitation. It had

7 G. Rudé, The Crowd in History: A Study of Popular Disturbances in France and England, 1730-1848 (New York, 1964), p. 185.

8 C. A. N. Reid, "The Chartist Movement in Stockport" (M.A. thesis, Hull, 1976), pp. 1-74, passim. No adequate study of the pre-Chartist labour movement in Stockport has been published, but fragmentary references can be found in a great variety of manuscripts, Parliamentary Papers, pamphlets and newspapers. For the post-1822 period, the best source is the weekly Stockport Advertiser. However, several important aspects of the subject are considered in G. Unwin, Samuel Oldknow and the Arkwrights (Manchester, 1924); A. Rose, "Early Cotton Riots in Lancashire 1769-1779", in: Transactions of the Lancashire and Cheshire Antiquarian Society, LXXIII and LXXIV (1963-64); A. Aspinall, The Early English Trade Unions (London, 1949); D. Bythell, The Handloom Weavers (Cambridge, 1969); D. Read, "Lancashire Hampden Clubs", in: Manchester Review, Autumn 1957; D. Read, Peterloo, the Massacre and its Background (Manchester, 1958); R. Walmsley, Peterloo: the case re-opened (Manchester, 1969).

${ }^{9}$ Stockport Advertiser, 18 December 1835. 
survived the arrest and imprisonment of its leaders in $1839^{10}$ and, in the spring of 1842 , local Chartists had been able to collect some 14,000 signatures for a second National Petition for the Charter. ${ }^{11}$ The rejection by the Commons of the Chartists' demands by no means affected the status of the movement in Stockport. If Chartist activity during the spring and summer of 1842 did not reach the level achieved in 1839 , this was due not to the emergence of any alternative leadership, but to the ever-increasing economic distress, which rendered the mere struggle for survival more pressing than political campaigns. ${ }^{12}$

If the working-class political activists were aligned behind the banner of Chartism, the majority of the manufacturers were faithful adherents of the Anti-Corn-Law League. Despite the addition of five Tory magistrates to the borough bench in November 1841, on the initiative of the Home Secretary, ${ }^{13}$ local administration remained firmly in the hands of WhigLiberal members. ${ }^{14}$ There was a Liberal majority on the Town Council, ${ }^{15}$ and at the 1841 General Election Stockport returned two Anti-Corn-Law Leaguers to Parliament, one of them being Richard Cobden. ${ }^{16}$ Between local Chartists and Leaguers there existed an antipathy based upon economic interests, which no political negotiations by national leaders could possibly eradicate. The Complete Suffrage movement failed to arouse any

10 Reid, "The Chartist Movement in Stockport", op. cit., pp. 148-69. For details of Chartist activities during 1839 see Anon., A Report of a Trial of Chartists, (The majority inhabitants of Stockport) For Conspiracy and Sedition, including that of the Rev. J. R. Stephens, of Ashton (Stockport, n.d. [1839]), passim. On 29 July 1839 police searched the homes of the leading local Chartists, where they found a collection of arms and ammunition. James Mitchell and Charles Davies were subsequently sentenced to eighteen months' imprisonment, at Chester Assizes in August, on a charge of conspiracy. Isaac Armitage junior, John Wright, James Burton, George Wareham and Thomas Howarth, who traversed to the 1840 Spring Assizes, all received one year's imprisonment, for having possession of arms for illegal purposes, and for conspiracy. Of these Chartists, only Wright and Richard Pilling, who was acquitted of the same charges in 1840, appear to have been active in the "Plug Plot".

11 Stockport Advertiser, 6 May.

12 Copy of Evidence taken, and report made by the Assistant Poor Law Commissioners sent to inquire into the State of the Population of Stockport [Parliamentary Papers, 1842, XXXV], passim.

${ }^{13}$ F. C. Mather, Public Order in the Age of the Chartists (Manchester, 1959), pp. 67, note, 68 .

14 N. McCord, The Anti-Corn Law League 1838-46, 2nd ed. (London, 1968), p. 121, states that in 1842, out of 59 magistrates in Manchester, Stockport and Bolton, there was hardly one (except the 7 Conservatives) who was not a member of the Anti-Corn-Law Association and League.

15 Stockport Advertiser, 5 November 1841.

16 Ibid., 2 July 1841. 
enthusiasm among Stockport Chartists. ${ }^{17}$ Yet the social classes were not completely polarized. There were a number of men who might be categorized as lower-middle-class, but whose interests were generally identified with those of the operatives. Shopkeepers, particularly the provision dealers, pawnbrokers and licensed victuallers were in many cases dependent for their own livelihood upon working-class prosperity. During the economic depression they had found themselves faced with declining trade, and an ever-increasing burden of poor rates. ${ }^{18}$ In the event of a wage demand by their actual or potential customers, they were not likely to prove unsympathetic.

The economic depression which had affected Stockport from the closing months of $1836^{19}$ had become increasingly severe by mid 1842 . A survey by the Poor Law Commissioners in 1842, based on returns from 17 Stockport firms, showed that the actual wages paid for a full week's work in 1841 were some $12 \%$ below the 1836 rates, while the cost of provisions had risen. ${ }^{20}$ In 1842 , however, a full week's work was the exception rather than the rule; since the summer of 1841 both unemployment and short-time working had shown a marked increase. ${ }^{21}$ The town had already witnessed a major attempt to combat wage reductions by means of strike action. The 1840 weavers' strike had dragged on for almost three months. It had culminated in the operatives returning to work at the reduced wages, only to face still further cuts, and the imprisonment of some of their pickets, on obstruction and conspiracy charges. The bitterness and hostility associated with this strike was long remembered in the town, ${ }^{22}$ and it would appear that neither manufacturers nor operatives were anxious for a repetition. When, in February 1842, Stockport manufacturers gave notice of a reduction in the wages of all their employees, amounting from between 10 to 20 per cent, ${ }^{23}$ there was no significant reaction.

Elsewhere in the country, the depression and wage reductions led to disturbances and strikes. Between April and June 1842 there were outbreaks among the nailers and colliers of Dudley, Stourbridge, West Bromwich and Rowley Regis; the Cumberland colliers; and the Glasgow

\footnotetext{
17 Northern Star, 7 May.

18 State of the Population of Stockport, op. cit., passim.

19 Ibid., pp. 45, 53.

20 Ibid., pp. 44, 79.

21 Ibid., pp. 8-14; Stockport Advertiser, 6 and 20 August 1841.

22 Northern Star, 2, 9, 16 and 23 May, 6, 13 and 20 June, 8 and 15 August 1840; Stockport Advertiser, 10 and 17 July 1840.

23 “Anti-Corn Law Agitation", loc. cit., p. 273. Northern Star, 19 February, claimed that employers were reducing the wages of dressers by as much as 7 shillings.
} 
masons. In July colliers on strike in the Potteries went from pit to pit, stopping engines by raking out the boiler fires, and pulling out the boiler plugs. On 21 July they marched northwards through Congleton and Macclesfield to Poynton, where their plans were hampered by the arrival of troops, together with a few members of the Stockport division of the Cheshire constabulary. ${ }^{24}$ By 7 August the Poynton colliers were again peacefully at work, ${ }^{25}$ but a strike had begun in the cotton district of Hyde, Ashton and Stalybridge.

Notice of wage reductions was first given by a Stalybridge firm on 9 July, and quickly emulated by its competitors in that town, and in nearby Ashton. ${ }^{26}$ Protest meetings were duly held, not only in these areas, but also in Hyde, Dukinfield and Droylesden. Demands were voiced for strike action, to obtain "a fair day's wage for a fair day's work", and also for the Charter to be made the law of the land. Most prominent among the Chartist speakers were two weavers, Richard Pilling and Alexander ("Sandy") Challenger, who had recently removed from Stockport to Ashton in search of work. ${ }^{27}$ The operatives' demands, as formulated in a placard entitled "The Voice of the People is the Voice of God", were however confined to economic measures: the wage rates of 1840 and a ten-hour working day, as a means of ending over-production. There was, moreover, an appeal for class co-operation, for the placard noted the effect of reduced wages upon the shopkeepers, and argued that a uniform price for the whole of the manufacturing districts would safeguard manufacturers against being undersold by their rivals. ${ }^{28}$ In spite of the efforts by the operatives' committee, and the willingness of some manufacturers to cooperate, one firm, Bayley's, still implemented the $25 \%$ reduction on Friday 5 August. On refusing to accept these terms, the operatives were dismissed. ${ }^{29}$

24 A. G. Rose, "The Plug Riots of 1842 in Lancashire and Cheshire", in: Transactions of the Lancashire and Cheshire Antiquarian Society, LXVII (1957), pp. 84-85. For an account of the disturbances in Congleton, see History of Congleton: published to celebrate the 700th Anniversary of the granting of the Charter to the town, ed. by W. B. Stephens (Manchester, 1970), pp. 94-95.

25 Major Hope to Col. Wemyss, Stockport, 7 August, Home Office Papers 45/269, Public Record Office.

26 Rose, "The Plug Riots", loc. cit., p. 86.

27 The Trial of Feargus O'Connor, Esq., (Barrister at Law,) and fifty-eight others, at Lancaster, on a charge of sedition, conspiracy, tumult, and riot (London, 1843), pp. 3, 13 , 17-19, 280-81; State Trials, New Series, IV: 1839-43 (London, 1892), c. 1102. For biographical details of Pilling and Challenger, see Reid, "The Chartist Movement in Stockport", pp. 427-28, 470-74.

28 The Trial of Feargus O'Connor, pp. 252-53.

29 Ibid., p. 332; Manchester Guardian, 17 August. 
That week-end was occupied by mass meetings, which revealed a dilemma among the operatives as to the nature and aims of the strike. Nor did unanimity reign within the strike committee; when a message arrived from William Bayley, that he wished to see some members of the committee, some of the strikers appeared ready to take part in a meeting while others, like the shoemaker Thomas Mahon, insisted that the men had come out for the Charter and would stick to it ${ }^{30}$ Concerning the necessity to extend the strike, however, there appears to have been general agreement. On Monday 8 August the participants in an early morning meeting at Stalybridge proceeded to divide into groups, and bring out hands from all the mills in the town. ${ }^{31}$ They were assisted by reinforcements from Ashton and neighbourhood, the parties consisting not only of spinners and weavers, but also of colliers, labourers, hatters, and workpeople of all descriptions. In the course of the turn-out, the strikers' numbers rose to about 5,000, around a third of them being female. From Stalybridge the strikers set out to Ashton, turning out factories and print works in Dukinfield en route. ${ }^{32}$ After more stoppages in Ashton and Hurst, a mass meeting was convened, which adopted Richard Pilling's proposal to divide into two parties. The people of Ashton were to lead a turn-out of the mills in Oldham, where Pilling had already made contacts, while the Stalybridge strikers were to concentrate upon enforcing the strike in Hyde. ${ }^{33}$

On the following day, contingents from mass meetings in both Stalybridge and Ashton marched into Manchester. Despite the presence of troops and police, they managed to hold a meeting in Granby Row Fields, and it was only after their orderly departure that workmen from the Manchester mills gathered together to inflict considerable damage. The Manchester operatives were responsible for the spread of the strike movement in that city and in Salford, on Wednesday 10th. On the same day, Pilling departed to Bolton, where he threatened forcible measures by the people of Ashton, should the strike not be implemented. The turn-outs of Ashton, Stalybridge, Dukinfield and Hyde proceeded to divide into two sections. One group set out to Mellor Moor, Dinting, Glossop, Tintwistle and Broadbottom; the other to Woodley, Apelhorn, Cross Moor, Compstall, New Mills and Disley. All the cotton mills on these routes were

30 Ibid., pp. 20, 27.

31 Ibid., p. 20.

32 Stockport Advertiser, 12 August.

33 The Trial of Feargus O'Connor, pp. 63-66; Rose, “The Plug Riots”, p. 90; Northern Star, 13 August. Pilling visited Oldham on Saturday 6th, to gain support for a turn-out, see The Trial, p. 74. 
stopped without opposition. On returning to Hyde, the strikers planned to visit Stockport on the following day. ${ }^{34}$

The strike movement outside Stockport has been considered at length for two principal reasons. Firstly, to illustrate the sheer extent of the turn-out; Stockport was now virtually surrounded by it, but still no spontaneous local gesture of solidarity had occurred. Secondly, accounts of the mass meetings reveal that the strikers had still not agreed upon an ultimate objective. The demand for the wage rates of 1840 was clearly a source of unity, but many of the most prominent leaders and speakers were also Chartists: Pilling, Challenger, Peter Brophy and Christopher Doyle. While mass meetings might raise a cheer for the Charter, there was no real commitment to that cause on the part of the vast majority of strikers. At a meeting in Hyde on 8 August, the opinion was voiced by a local tailor, John Leach, that the stand should be made for wages, rather than the Charter, as he believed it was impossible for them to obtain the Charter at the present time. ${ }^{35}$ At least one participant in the meetings had another motive. George Southam, chairman of the Ashton meeting on 9 August, was both a cotton manufacturer and member of the Anti-Corn-Law League. It was he, rather than Pilling, who pressed for an immediate march to Manchester, in order to extend the turn-out. On this occasion he observed:

I should like to be put into the way how the wages of 1840 could be paid. I, for one, would be glad to pay them, but I do not think it could be done until the Corn Law is repealed. ${ }^{36}$

Southam, an employer who was prepared both to participate in the strike and declare himself a Chartist, was however the exception rather than the rule. During the course of the strike in Stockport, the repeal of the Corn Laws never loomed large as a major objective. The differences between Chartists and trade unionists were, on the other hand, more apparent than they had been in the early stages of the strike in Hyde, Ashton and Stalybridge.

The Stockport authorities had, in that summer of 1842 , been aware of the likelihood of some popular disturbance. It would appear that their suspicions had been concentrated upon the Chartists, for members of the police had been sent to attend meetings, and report to the Superintendent, Joseph Sadler. ${ }^{37}$ The idea of a "National Holiday" or "Sacred Month" to

34 The Trial, pp. 21 , 74, 100; Manchester Guardian and Northern Star, 13 August.

35 Ibid., p. 21.

36 "Anti-Corn Law Agitation", p. 294; Northern Star, 8 October.

37 Report of Stockport Chartist meeting, addressed to Mr Sadler, 2 June, Stockport Chartist Papers, Library of Local Studies, Archives Collection, Stockport Central Library (hereafter SCP). 
pressurize Parliament into granting the Charter, was of long standing, but there is no evidence of any definite Chartist plan for a strike in Stockport at this time. Indeed, once the turn-out had commenced in the neighbouring towns, the Stockport magistrates assessed, very accurately, that the threat to public order stemmed not so much from the local Chartists, but from the arrival of strikers from other districts. Much of the magistrates' time on 9th and 10th August was therefore expended upon swearing in special constables, and despatching requests for troops. ${ }^{38}$ Upon the advice of Col. Wemyss they prepared, not to oppose the entry of turn-outs into the borough, but "to act according to emergency should any illegal act be proposed". 39

\section{III}

On Thursday 11 August, the turn-outs of Hyde and Compstall assembled at Hyde, whence the body of between six and eight thousand men and boys commenced a march to Stockport. Equipped with large sticks, which they kept waving above their heads, they entered the town around noon, and proceeded to turn out all the mills and factories along their route, with little opposition. The only real conflict came at Messrs Bradshaw's mill in St Petersgate, when James Bradshaw's refusal to admit the strikers resulted in an attack upon the mill, and a severe beating for Bradshaw himself. In the course of such proceedings, reinforcements from Ashton joined the strikers, and assisted in the task of stopping mills, by pulling the fire from under their boilers. Increasingly alarmed, the authorities collected all the special constables in the Court Room, and stationed a guard of troops, police and auxiliaries, all of whom wore cutlasses. The magistrates, together with the rest of the military, then proceeded to the Market Place, where the Mayor read the Riot Act. Placards informing the populace of this event were posted in all parts of the town, and the military ordered to remain in the Market Place, to be ready to act in cases of emergency. ${ }^{40}$

38 W. Nelstrop to Sir James Graham, Stockport, 10 August, HO 45/242; Maj. Gen. Warre to S. M. Phillipps, Manchester, 10 August, HO 45/268; E. J. Lloyd to W. Nelstrop, Warren Bulkeley Arms (Stockport), 11 August; Lord Stamford to Mayor of Stockport, Dunham Massey, 10 August; H. Manners Sutton to Mayor of Stockport, Whitehall, 11 August, SCP.

39 Report of meeting of Stockport Borough Magistrates, 9 August, SCP. These reports appear on separate sheets of paper, and with slight variations in headings. However, they will hereafter be cited as Magistrates' meeting.

40 Magistrates' meeting, 11 August; Stockport Advertiser, 12 August; Manchester Guardian, 13 August. For details of the attack on Bradshaw's mill, see The Trial of Feargus O'Connor, p. 89, evidence of James Bradshaw. R. G. Gammage, History of the Chartist Movement 1837-1854, 2nd ed. (1894; facsimile reprint 1969), wrongly cites this event as taking place on 16 August. See also HO 45/242, deposition of James Bradshaw. 
At about 2 p.m., the turn-outs began to assemble on Waterloo Road. A cart was drawn up, and a meeting opened, with the Chartist John Wright in the chair. The demand was again made for the wages of January 1840, and a resolution passed, to the effect that all producers of wealth should cease from labour, until a conference had been elected to meet in Manchester on Wednesday 17 th, by whose decision the strikers should abide. It was also resolved that the shopkeepers should be called on to support the strike, as they were doing in Ashton and Stalybridge. ${ }^{41}$ Thus despite the political allegiances of the Chairman, there is no evidence of any Chartist attempt to assume the leadership of the strike movement. Indeed at this stage the Stockport turn-outs appear to have lacked any concerted leadership, for while the meeting on Waterloo Road was still in progress, another group had set off towards the Union Workhouse on Shaw Heath. Armed with sticks and bludgeons, they broke into the workhouse and proceeded to help themselves to about 700 seven-pound loaves of bread, and about $£ 7$ in cash. Magistrates, military, and special constables then appeared on the scene, and proceeded to take about forty prisoners. When news of the arrests reached the Waterloo Road meeting, a large body decided to set off to the rescue, against the advice of the speakers. The latter group, led by John Wright and John Leach of Hyde, formed a deputation, which waited upon the authorities, to request the liberation of the prisoners. Meanwhile the "rescue" party, which had arrived at Shaw Heath waving sticks, and bearing several loaded pistols, had found the cavalry formed up with drawn swords, and ready to charge, and the infantry and special constables in the workhouse yard. Faced with this show of strength, and believing that the deputation had secured the release of all the prisoners, they turned back along Waterloo Road. Speeches made in the course of their retreat, and at a meeting held that evening, advised the operatives to be peaceable. News spread through the town that seventeen of the prisoners had, however, been committed for trial. ${ }^{42}$

Concerning the beginning of the strike in Stockport, certain observations may be made. Initially, it did not take the form of a spontaneous gesture of solidarity with the strikers in the neighbouring towns. In a speech delivered several days later, on 15 August, Richard Pilling castigated the Stockport operatives:

It was the Ashton lads that turned you out; and mind one thing, if you do go in, they will come over and give you a $\mathrm{d}-\mathrm{d}$ good hiding. They then went to

41 Manchester Guardian, 13 August.

42 Magistrates' meeting, 11 August; The Trial of Feargus O'Connor, pp. 41-42, 45-46; Manchester Guardian, 13 August. 
the bastile [workhouse]; but I did not consider that right; but this winter we may all become tinieves, and then the soldiers and police will have to look after us; and that will eat up the system, as there are more ways than one of eating up the system; but, if the Ashton lads had not been there, they would not have known that there had been such a place.

He went on to warn his audience:

But you must be sure and stick out, and not go to your work; for, if you do, the masters will crush you down, you may depend upon it, and then the Ashton lads will come over again, and give you a d-d good hiding; and don't you deserve it? ${ }^{43}$

The attack on Stockport workhouse has often been acclaimed as a local "storming of the Bastille", a conscious political protest led by the Chartists. This interpretation is actually far removed from the facts of the situation. Both the original attack and the "rescue" expedition were undertaken against the advice of Chartist speakers. Nor can the people involved in these events be identified as local Chartists, or even as working-class activists. ${ }^{44}$ Moreover their motives cannot be described as political. The statements from prisoners reported in the Stockport Advertiser all reveal their desire to obtain bread, or merely their willingness to accept bread from others, who had taken part in the actual break-in. A typical statement is that of Ann Hibbert, who in her defence stated that

she was standing near the Workhouse when a young woman said "let's go in th' Workhouse; they say it's a very nice place inside; come, let's go and see". They accordingly went, and in the lobby where there was a good deal of "thrutching", one man who had two loaves said "young woman will you have one". She said "aye" and took it "whoam" with her. ${ }^{45}$

The attack on Stockport workhouse thus emerges as a pillaging expedition by hungry people. Not that this factor helped the participants; sentences passed on the prisoners ranged from transportation for life to a year's imprisonment with hard labour. ${ }^{46}$

The strike in Stockport had thus been triggered off through external pressure, rather than through any local impetus. Pilling, at least, seems to have doubted whether it would continue without the actual or threatened appearance of his "Ashton lads". It might also be remarked that, while the Stockport operatives had readily acquiesced to the strike demand, their

43 The Trial of Feargus O'Connor, pp. 53-55.

44 Stockport Advertiser, 16 and 30 September. See also letter to Mayor and magistrates of Stockport from Hadfield and others, prisoners in Chester Castle, 13 August, SCP.

${ }^{45}$ Stockport Advertiser, 16, 23 and 30 September, 7 October.

46 Northern Star, 15 October. 
employers were not completely hostile. Obviously, given that a large body of strikers was approaching an undefended mill, its owner would stand to make a smaller loss by closing it without resistance, than by attempting to make a stand and risking serious damage to his machinery. ${ }^{47}$ Moreover, the amount of money which he would lose through a closure at that time was far less than would have been the case in a period of prosperity. Manufacturers were already working their mills short-time, because of the state of trade. To close for a few days when orders were scarce might even have produced a saving in labour and running costs. Indeed, when the gradual return to work did begin, manufacturers did not always keep their mills running. According to the Manchester Guardian on 24 August, "Some of the engines were stopped by half past six in the morning; the hands who had resumed work being so very few, that it would not pay to run the engines." 48 Three days later, a letter to that paper on the same subject, signed "A manufacturer", stated that "The manufacturers having no inducement to commence working on the score of profit (some having been working short time for several months), it is not likely that the offer will be repeated." ${ }^{9}$ The suggestion that the manufacturers' failure to resist the strike signified some Anti-Corn-Law League plot $^{50}$ thus appears rather far-fetched. A desire to protect machinery and possibly save running costs seems likely to have been far more prevalent than the belief that a strike situation would ultimately oblige the Government to repeal the Corn Laws. Thus the Stockport operatives had been neither manipulated by the Anti-Corn-Law League, nor recruited to the ranks of Chartism. The only aim which they appear to have held in common was that of the restoration of the 1840 wage rates. Even so, they had no "official" trade-union leadership either. By the evening of Thursday 11 August, Stockport was on strike, but whether the impetus of that strike would remain concentrated upon industrial issues, or whether it might be directed towards a wider political aim, was dependent entirely upon the course of future events.

The immediate aftermath of the turn-out represented a consolidation of positions, rather than any change in the direction of the strike. The strikers began their activities on Friday 12 August, with a meeting at 5 a.m. They then formed into a procession, which marched round the town, to ensure the continued closure of the mills, before dividing into two sections. One

47 James Bradshaw was frequently advised against offering resistance to the strikers, on the grounds that, by so doing, he would only encourage violence. See his deposition HO $45 / 242$.

48 Manchester Guardian, 24 August.

49 Ibid., 27 August.

50 For example, see "Anti-Corn Law Agitation", passim. 
party remained in Stockport, while the other set off to extend the strike to Macclesfield. The magistrates, upon hearing rumours that a second attack on the workhouse was planned when the Macclesfield party returned, expended most of their time and energy in making arrangements with the military. ${ }^{51}$ The attack never materialized, both parties being more profitably engaged in levying "contributions" from manufacturers, particularly those who, like Mr Jackson of Heaton Mersey bleach works, obtained permission to continue working until certain pieces, undergoing a chemical process, had been completed. ${ }^{52}$

The strike still appeared to be directed towards industrial, rather than political, goals. Such goals were, however, open to constant change. There was no definite "strike committee" as such; any proposals which were actually put to a vote were considered at mass public meetings. These were open to anyone and everyone, and might vary considerably in composition from one day to the next. Since 1838 the Chartists had generally taken the lead in working-class protest movements in the town, but even their future plans for the strike were not as clear-cut as might have been expected. Admittedly the situation resembled that of the "Sacred Month" or "Grand National Holiday of the Working Class", which had been mooted as an "ulterior measure", to force the Government into acceptance of the Charter. But when the Northern Star appeared on Saturday 13 August, it became clear the O'Connor entertained no hopes for a "strike for the Charter". The Star simply advised the working class to avoid being used by the Anti-Corn-Law League, which, according to O'Connor, had brought about the strike. A strike could not be effective as a Chartist tool unless it became a national movement, but it lacked the organization and financial backing so to do. It would, moreover, bring to many people greater suffering and destitution than before, and cause others to be wounded or imprisoned; it would eventually serve only the purpose of the enemy. ${ }^{53}$ Such advice, rational as it may have appeared to anyone uninvolved in the strike, was not easy to accept. The majority of the local Chartists were cotton operatives and were already participating in the turn-out, regardless of any future aims. Given that the strike was a fait accompli, failure to

51 Magistrates' meeting, 12 August; Samuel Forster to Mayor of Stockport, Stockport, 12 August, SCP; Mayor of Macclesfield to H. O. Macclesfield, 12 August, HO 45/242; Manchester Guardian, 13 August.

52 Manchester Guardian, 17 August. The matter of authorization to firms to continue working during the strike was later investigated by the Home Office. See H. Manners Sutton to W. and J. Bradshaw, Whitehall, 8 September, HO 41/17; also HO 45/242, deposition of Charles Poppleton.

53 Northern Star, 13 August. 
direct it towards Chartist objectives must have appeared as a wasted opportunity. Accordingly, at a meeting on 13 August, John Allinson, Joseph Carter, John Wright and Christopher Doyle all advocated the Charter. ${ }^{54}$ Despite a speech from a man named Ellis, favouring the exclusion of both politics and religion from the present struggle, the meeting now proceeded to vote in favour of the Charter. ${ }^{55}$

The political ramifications of the strike had no apparent effect upon the local authorities, whose principal fear was of mob violence and the destruction of property. Appeals were made to Major General Sir William Warre in Manchester, and to the Home Secretary, for an additional military force, while heaps of stones, which seemed convenient potential missiles for any attack on the Court House, were hastily removed under military supervision. ${ }^{56}$ The Chartists, however, appear to have been more interested in preparations for two camp meetings, to be held on Sunday 14 th, and a public meeting on Monday 15th. A placard was issued forthwith, in the name of "the Chartist Council of Stockport". ${ }^{57}$ The camp meetings, a type of gathering developed from the organization of the Primitive Methodists, ${ }^{58}$ were held behind the arches near the railway station. Christopher Doyle in the afternoon, and James Leach in the

54 For biographical information on Allinson and Carter, see Dictionary of Labour Biography, ed. by J. M. Bellamy and J. Saville, II (1974), pp. 10-11, 93-94. For Wright see Reid, "The Chartist Movement in Stockport", pp. 498-99. Wright was a spinner who had been active in the Stockport Chartist movement since 1838. He was arrested and imprisoned as a result of his Chartist activities in the summer of 1839. In 1841 he took part in attempts to extend the Chartist movement to Ireland. During the "Plug Plot" Wright was elected as a delegate to the Manchester Trades Conference and, as chairman of the Stockport Chartists' committee, he also signed "licences", giving sanction to some operatives to continue working through the strike. Although arrested, he did not appear among the defendants at the Chartist trial at Lancaster in 1843. Doyle, a weaver from Manchester, had already served nine months' imprisonment for Chartist activities there in 1839. He was tried at Lancaster in March 1843 for his part in the "Plug Plot", and later became both a member of the National Charter Association executive and a director of the National Land Company. See The Trial of Feargus O'Connor, pp. 266-71; Ward, Chartism, pp. 132, 137, 171-72, 174-75, 179, 181, 183, 193, 195, 204, 206-07, 219, 222, 225, 228, 237; A. M. Hadfield, The Chartist Land Company (Newton Abbot, 1970), pp. 18, 21, 25, 33, 42-43, 70, 72, 76-77, 91, 102, 104, 108-10, 127, 130, 154-57, 188, 190-93, 207-08, 210. 55 Stockport Advertiser, 19 August; Report of Meeting on Waterloo (ground), (Stockport) 13 August, SCP.

56 Stockport Advertiser, 19 August; H. Manners Sutton to Mayor of Stockport, Whitehall, 13 August; Major Hope to Mayor of Stockport, (Stockport) Barracks, 13 August; Jonathan Thornhill to Capt. Lloyd, Stockport, 13 August 1842; Jonathan Thornhill to Major Hope, Stockport, 13 August, SCP.

57 One of these placards is preserved in HO $45 / 242$.

58 R. F. Wearmouth, Methodism and the Working-Class Movements of England 1800-1850 (London, 1937), pp. 138-42, passim. 
evening, both made political speeches in favour of the Charter to audiences of about 2,000.59 The size of these meetings cannot, however, be taken as a true indication of the actual number committed to a strike for the Charter. Indeed the presence of large numbers of apolitical and uncommitted strikers at the meetings might prove a hindrance rather than a help to the leadership. On 13 August was issued a Royal Proclamation, offering a reward of $£ 50$ for information leading to the arrest of men who prevented, by threats and intimidation, others from following their usual occupation. The money, coupled with the promise of pardon for such offences committed by the informer, ${ }^{60}$ must have been a great temptation! In November and December 1842, long after the termination of the strike, James Crompton and Thomas Mather of Stockport, as well as Robert Radcliffe from New Mills, all claimed rewards under the terms of the Royal Proclamation. ${ }^{61}$

\section{IV}

The number of men who actually turned government informers or, more likely, were deterred from further activity, did not have any fundamental effect upon the course of the strike. Of far greater importance was the widening gulf between the two principal groups of activists: the Chartists and the adherents of the "wages only" campaign. Monday 15 August witnessed a major attempt to counterbalance the influence of Chartism, and to provide a definite leadership for the purely industrial movement. That morning a meeting was held on Waterloo Road, at which Doyle, Wright and Webb all argued the Chartist case, while a section of operatives represented by John Ellison and John Weatherhead pointed out the impolicy and danger of mixing other matters with the question of wages. ${ }^{62}$ The latter group apparently constituted the majority at this meeting, for a

59 Stockport Advertiser, 19 August. Despite the spelling "Leech" on the placard, the speaker was indeed James Leach, a Manchester Chartist who was becoming increasingly prominent in the national movement, see Read, "Chartism in Manchester", loc. cit., pp. $50,52,56$. Identities can easily be confused, for also active in Stockport was John Leach, a tailor from Hyde, who claimed to have led the people up to the workhouse on 11 August, see The Trial of Feargus O'Connor, p. 30; Joseph Hibbert to Messrs Coppock and Woollam, Solicitors, Hyde, 15 August; J. Little to J. Sadler (Chief Superintendent of Police, Stockport), Hyde, 21 August 1842, SCP. The last refers to John Leach as "the Chartist speaker".

60 Royal Proclamation, 13 August, SCP.

61 S. M. Phillipps to Magistrates for Division of Stockport, 23 November; id. to Thos. Mather, Heaton Lane, Stockport, Whitehall, 16 December; id. to Thomas Mather, Whitehall, 19 December, HO $41 / 17$.

62 Stockport Advertiser, 19 August. 
resolution was passed, to the effect that the Charter was not a fit subject at a turn-outs' meeting. A deputation, comprising Ellison, Weatherhead, John Newton and James Selby, was formed to wait upon the Mayor and magistrates, with a request for them to lead a procession of operatives who had struck for wages only. The operatives, for their part, would do their utmost in preserving the peace of the borough. They also wanted the magistrates to use their influence to induce the manufacturers to pay the January 1840 wage rates, and requested permission to hold public meetings on the subject of wages only. The magistrates refused the first two requests, but assured the deputation that they would not interfere with peaceful meetings. ${ }^{63}$

That afternoon another meeting, of between five and six thousand people, took place on Waterloo ground, again chaired by Wright. Presumably its chief purpose was to hear the report of the deputation. Despite his own Chartist allegiance, Wright is reported as having urged, "that they would keep peace and order and as it was to be a wage question to keep to that alone". Newton even proposed "that whoever introduced any subject not connected with wages should be put down". The latter did, however, lose the support of the meeting when he urged the people to go to London to demand their wages, and was consequently accused of being a tool in the hands of the Anti-Corn-Law League. It was on this occasion that Pilling made his most famous speech, that in which he described himself as "the father of this movement". The movement he described was, however, a struggle against wage reductions, rather than the campaign for the Charter. ${ }^{64}$

This gathering was also notable for the absence of a large section of strikers. Early in that afternoon, a meeting of foremen, overlookers, managers, and delegates of all descriptions of trades employed in the borough, was held at the Cotton Tree Inn, Heaton Lane. John Weatherhead, the leading advocate of the "wages only" policy, took the chair. It was now resolved that a General Central Committee be formed of all overlookers, foremen and managers of every branch of the trade of the town and neighbourhood, for the purpose of obtaining by legal and constitutional means the prices paid for their labour on 1 January 1840. This Committee was intended to sit at the Cotton Tree until the strike was

63 Manchester Guardian, 17 August; Magistrates' meeting, 15 August, SCP. Of the deputation, Weatherhead was an overlooker, Selby a spinner, John Ellison a weaver, and John Newton a stone mason.

${ }_{64}$ Report of Meeting at Waterloo Road, 15 August, SCP; The Trial of Feargus O'Connor, pp. 53-55. 
over. ${ }^{65}$ It was presumably from this meeting that there emanated a large unsigned placard, addressed "to the Working Classes of Stockport And its Vicinity". The placard merits quotation in full, for it represents the major attempt to provide firm leadership for the "wages only" movement:

In consequence of the repeated solicitations that have been made upon us by great numbers of the well-disposed Operatives of our Town and Neighbourhood, lamenting that the present contest betwixt the Employers and Employed should be left in such a vague and unbusiness-like manner, without any systematical Rule of action to proceed upon: for if we come in contact with your Employers, we are asked what have you Turned-out for? and what answer can we give to that question; for when we attend your Public Meetings, we are sorry to find you are contending about Party Politics; but upon examination, we perceive that the major part of them thus contending, are Young and Inexperienced people, who are led away by the impulse of the moment. In addition to the numerous and well-disposed Inhabitants that have waited upon us, some of them with Lists of Prices from their respective Mills, seeking for a Committee to lodge their respective Lists, in order that some General Plan may be adopted for the wellbeing of all. In addition, we have also been waited upon by several Deputations of Operatives and other Classes, hoping that we will take up the subject, and point out some Systematical Plan, by which their differences may be brought to some speedy and beneficial determination. Under these circumstances, we believe, in order to be successful, there ought to be one General Rule of Action for the whole; and seeing that Stayley Bridge, Ashton, and its Vicinity have struck out a Plan, and believing it to be a good one, we pledge ourselves to assist both pecuniarily and otherwise, if this be acted upon in our Town and Neighbourhood.

\section{THE PLAN IS AS FOLLOWS:-}

1st. - Neither Politics nor Religion shall be allowed to interfere with the subject of Labour and Wages.

2nd. - That a Deputation from every department of labour from each and every Mill and Shop in the town and neighbourhood, attend at the COTTON TREE, Heaton Lane, on TUESDAY the 16th inst, between the hours of 10 and 12 o'clock in the forenoon, and 6 and 8 in the evening, and bring with them a list of prices which they received for their work, January 1st, 1840, and appoint a Delegate to attend a General Conference, to draw out one general list of prices for the united kingdom, if possible, also to appoint a Deputation to wait upon the Manufacturers, TO ASCERTAIN WHAT PRICES THEY ARE PREPARED TO GIVE. ${ }^{6}$

65 Stockport Advertiser, 19 August.

${ }^{66}$ To the Working Classes of Stockport and its Vicinity, Stockport, August 15, 1842, Printed by James Lomax and Sons, Advertiser-Office, Stockport, SCP. 
This meeting, and the proposals thus published, revealed the division of interest among the working classes of Stockport. In the forefront of the "wages only" movement were the more affluent workers - foremen, overlookers and managers - together with groups outside the cotton industry, such as tailors, smiths (who had not suffered from reductions since 1840) and the handloom weavers, who looked upon the power-loom weavers as the source of their own sufferings. ${ }^{67}$ It might be reiterated here that the local Chartist movement tended to draw its membership from the cotton operatives. ${ }^{68}$

Subsequent activities by the Committee at the Cotton Tree Inn have not been recorded, but its very existence presented a strong alternative to Chartist leadership in the strike. It should not, however, be assumed that the majority of strikers adhered to any distinct policy. The turn-out was in essence a hunger movement, and some parties of men were simply engaged in moving round the district pillaging and obtaining alms by intimidation. ${ }^{69}$ A certain number of politically non-committed strikers seem likely to have attached themselves to the crowds, regardless of the exact aims of the particular march or meeting. Thus on Tuesday 16th the Hunt Memorial demonstration took place in Manchester and, after a meeting on Waterloo Road, the majority of Stockport strikers set off to attend. ${ }^{70}$ Feargus O'Connor's passage through Stockport station, aboard the Birmingham-Manchester train, was duly noted by an informer, John Murnane, and reported to the Mayor of Stockport. ${ }^{71}$ Certainly the Stockport local authorities feared more widespread concerted action by the strikers, as a result of the Manchester gathering. The Town Clerk was despatched forthwith to consult with the Mayor and magistrates of

67 Stockport Advertiser, 19 August. The handloom weavers' delegate at the meeting, Francis Higgins, said: "The fact is, we want those who are better off to assist us in our struggles; because, while they were working, they contributed towards assisting other masters with the means of bringing us down."

68 Reid, "The Chartist Movement in Stockport", p. 233, Table 1. It has been possible to ascertain, with a reasonable degree of accuracy, the occupations of 72 Stockport Chartists. Of these men, 49 were engaged in some capacity in the cotton industry.

69 Stockport Advertiser, 19 August; Public Notice, issued by Stockport Magistrates, 15 August, SCP. The magistrates attempted to end this practice by advising inhabitants that obtaining alms by intimidation consituted a felony, and requesting information which might lead to the apprehension of these parties. Similar notices were issued for Macclesfield and Cheshire, see placards issued by William Adamson, Special High Constable, Macclesfield, 15 August, and E. D. Davenport, High Sheriff of Cheshire, 16 August. See also letter Thomas Stringer, Mayor of Macclesfield, to Mayor of Stockport, Macclesfield, 16 August, SCP.

70 Stockport Advertiser, 19 August.

71 John Murnane to Mayor of Stockport, Stockport Station, 16 August, SCP, 
Manchester, but was obliged to report "that they are acting in their own District only and that there was no line of conduct laid down or any combined action throughout the District". ${ }^{72}$

The meetings in Manchester did not, however, produce any renewed fervour among the strikers. Admittedly Stockport delegates attended the Manchester Trades Conference, which began on Monday 15 August, but the passing of a resolution to continue the strike until the Charter was obtained, did nothing to resolve the differences among the Stockport strikers. ${ }^{73}$ The Stockport delegates were not, apparently, very well received at the conference. When they reported back to a public meeting of about ten thousand people, held on Waterloo Road on the evening of the 17th, one delegate, named Flanigan, complained of the uncourteous manner with which the Stockport men had been received. He said that, when the Stockport delegation had entered, the meeting had quickly been adjourned until the next day. This attitude he attributed to the Stockport operatives' decision not to mix the Charter with the wages question. The adherents of the "wages only" movement were in fact a very small minority at the Trades Conference; out of 85 delegates, 58 declared for the Charter, 19 were prepared to abide by the decision of the meeting, and only $7 \mathrm{ad}$ vocated confining the strike to the wages issue. The "odd man out", from the Manchester stone masons, said that his constituents individually supported the Charter, but he had no instructions from them as a body. ${ }^{74}$ Subsequent meetings on Waterloo Road on Thursday and Friday (18th and 19th) failed to produce any definite agreement on the Charter/wages question among the Stockport strikers. The Charter was advocated by Joseph Harrison, John Wright, James Mitchell and a Mr Carter, but no effective decision taken. ${ }^{75}$ The second of these meetings, however, ended abruptly when someone in the crowd complained that smoke was emerging from the chimney of Christy's hat shop! ${ }^{76}$

This was not the first manifestation of an attempted return to work. On Wednesday morning the fires had been kindled under the boilers of Lower Carr Mill, although they had soon been pulled out by the strikers. But on Tuesday and Wednesday, all the boot- and shoemakers had resumed work

72 Magistrates' meeting, 16 August.

73 Northern Star, 20 August.

74 Manchester Guardian, 20 August.

75 Stockport Advertiser, 19 August, states that the meeting on Friday resolved to adhere to the determination of the Manchester Conference, viz. the Charter, but according to the Manchester Guardian, 20 August, no decision was reached at either meeting. Certainly there ensued no concerted action on behalf of the Charter.

76 Manchester Guardian, 20 August. 
without opposition. The authorities, apparently encouraged by this sign, had offered protection to all who were inclined to return to work, but feared molestation. ${ }^{77}$ On Friday 19th, after raking out the boiler fires at Christy's, the crowd dealt in the same manner with attempts to resume work at Carrington's hat factory and Sykes's bleach works. They dispersed only on hearing that the cavalry and special constables were approaching. ${ }^{78}$ The local authorities clearly expected disturbances to result from protests against a resumption of work, and attempted to prepare for eventualities by requesting troop reinforcements ${ }^{79}$ and also by issuing a ban on all public meetings in or near the town. ${ }^{80} \mathrm{~A}$ meeting was actually held on Waterloo Road on Saturday 20 August, but the total attendance proved small, and remained divided in to separate groups of about 30 each throughout the proceedings. The Stockport delegates appointed to the Manchester Conference naturally met to discuss the ban, and proceeded to issue a resolution advising clubs and societies to make a run on the banks, in order "to provide the poor with bread, until the rights of the people are established". The chairman of their meeting, John Wright, who also acted as the Chartists' bellman and bill-poster, was in the act of posting a bill to this effect, when he was arrested. Wright was committed to Chester for trial, on a charge of conspiracy. When offered bail, he refused, saying that he could not maintain his wife and family if he was at home. ${ }^{81}$

Thus the Chartists now faced opposition from all sides. A large proportion of the strikers had never been committed to their cause anyway, and growing numbers were obviously contemplating a return to work, with or without wage increases. But although the Chartists were not in fact the undisputed leaders of the strike movement in Stockport, the local authorities apparently believed them so to be. Admittedly the Chartist movement did produce some of the leading orators, whose speeches provided memorable copy for the police reporters. They were the obvious targets for any show of strength by the local authorities, who had not yet forgotten the arms and ammunition discovered during the Chartist arrests of 1839. ${ }^{82}$

77 Ibid. For the magistrates' placard, see Public Notice, Court House, Stockport, 16 August, HO 45/242. A further copy of this placard is contained in SCP.

78 Manchester Guardian, 20 August.

79 Major Hope to unknown, Stockport Barracks, 18 August; H. Manners Sutton to Mayor of Stockport, 20 August, SCP.

80 Placard issued by Mayor of Stockport, 19 August, HO 45/242. A further copy of this placard, together with a manuscript draft, is contained in SCP.

81 Manchester Guardian, 24 August.

82 See Reid, "The Chartist Movement in Stockport", pp. 119-47, passim, for details of "physical force" Chartism during 1839. 
Had the situation been truly revolutionary, and the strikers united by a common cause, the civil and military forces might well have proved inadequate. ${ }^{83}$ As it was, the special constables themselves now began to assist the wages movement, in an attempt to bring about a peaceful solution to the strike.

During the preceding week-end, the main question had been as to whether any mills would open on Monday $23 \mathrm{rd}$. A placard was issued by the master spinners and manufacturers, announcing that the mills would open on that day, and that protection would be afforded to those who were willing to return to work. Since no mention was made of any advance in wages, the majority of the population decided against returning to work. Strikers in neighbouring localities were, however, unsure of the solidarity of the Stockport men, and plans were made for a meeting at Godley Green, near Hyde, which was to culminate in a march upon Stockport. ${ }^{84}$ On Monday morning, all the cotton mills were therefore opened, with the manufacturers expecting that the operatives would be glad to return to work after a week without wages. By 6.30 a.m. the lack of labour had already stopped some of the mills, and by noon the rest had followed suit. Meanwhile, 6,000 men and boys had assembled at the Chartists' rooms in Bomber's Brow, between 4 and 5 a.m., and had set off for the meeting at Godley Green. A large body of special constables, together with the yeomanry cavalry, therefore proceeded as far as the Traveller's Call in Bredbury, to prevent any rioters from entering the town. All suspiciouslooking people were stopped and examined, and any offensive weapons found in their possession removed. After a time, the force returned to Stockport, and a party of special constables, composed of shopkeepers and others, assembled at the Vernon Arms,

and no doubt tired of the harassing duties which had of late kept them much from their homes and business, and the distant prospect of the dispute between employers and operatives being terminated, entered into a discussion as to the propriety of endeavouring to effect a reconciliation between the two parties. A deputation was appointed to wait upon the mayor, to request his assistance and co-operation in effecting so desirable an object. ${ }^{85}$

83 Ibid., pp. 207-09.

${ }^{84}$ Stockport Advertiser, 26 August; placard issued by Cotton Spinners and Manufacturers of Stockport, Stockport, 20 August, SCP. For information concerning the proposed march to Stockport, see Harris Sheppard (?) to Mr Billingham, Glossop, 21 August; Edward Appleton, Clerk to Stalybridge Magistrates, to Mayor of Stockport, Stalybridge, 22 August; Thomas Stringer, Mayor of Macclesfield, to Mayor of Stockport, Macclesfield, 22 August, SCP.

85 Manchester Guardian, 24 August. 
Such an extract from the Manchester Guardian's report clearly shows that the depression and strike were making their mark upon the lower middle class of the town. Not only was their own livelihood suffering as a result of the impoverishment of the working class, but they were expected to neglect their own businesses in order to serve as special constables. Attempts to avoid service were common; on Wednesday 24 th, no less than 47 men were summoned for either refusing to be sworn in as special constables, or failing to attend on the previous Monday. ${ }^{86}$

The Mayor, in his official capacity, refused to intervene in the dispute, but the special constables resolved to continue their efforts. The result was a placard issued on the Tuesday morning.

To the Trades of Stockport. - Workmen, you are requested by the Special Constables to hold separate Meetings for the purpose of appointing delegates, provided with lists of the Wages paid in 1840, and lists of the Wages paid now, to each branch in each Factory; for they (the Special Constables) say the Manufacturers may be induced to listen to the just demands of labour, that the dreadful state of excitement and wretchedness which now so unfortunately pervades the whole of our country, may be put an end to. - The Spinners will meet in the Juveniles' Room, Bombers Brow, at Ten o'clock this Forenoon. - The Power Loom Weavers will meet in the Chartists' Room at Eleven o'clock. The Card Room hands will meet in the Chartists' Room at One o'clock. - The Throstle Room hands will meet in the Juveniles' Room at One o'clock. - The Hand Loom Weavers will meet in the Catholic Total Abstinence Room at Twelve o'clock: and all other Trades in their respective places, at as early an hour as possible. - The delegates will meet at the Sir John Falstaff, in Bridge field, at Three o'clock this Afternoon. - P.S. There is some Bread to be divided amongst the poorest of the Turned outs, which Duty the delegates will be expected to perform. - Aug. 23d, 1842.

It would thus appear that this section of the middle class of Stockport was now prepared to give definite assistance to the strikers' wage campaign, and that they had, moreover, some degree of co-operation from the Chartists.

What happened at the meeting advertised by the placard has not, unfortunately, been reported. That evening, however, the tradesmen and representatives of the different branches of cotton operatives met in the Vernon Arms. According to the Stockport Advertiser, "Some indiscretions were committed in the warmth of debate by some of the speakers, affecting their allegiance to the oath to which they had subscribed as conservators of the public peace". The men here referred to were presumably the special

86 Stockport Advertiser, 26 August. 
constables. As a result of the meeting, a committee of seven tradesmen was appointed to wait upon the masters with a list of prices drawn up in Manchester. The operatives received a report of this meeting from their delegates on Wednesday 24th, when a public meeting was held on a large piece of ground near one of the railway arches on Wellington Road. The Chartists were represented here by Ellison, Joseph Carter and Thomas Clark, who had recently fled from Nottingham. ${ }^{87}$

In spite of the special constables' efforts, the strike dragged on, although without major incident. Attempts to re-open the mills were again made on Monday August 29th, with no more promising result than in the previous week. Parties of turn-outs took action when factories attempted to resume, as in the case of two candle-wick factories in Mottram Street and Portwood, on Thursday September 1st. Money was drawn from the boxes of sick and burial clubs in order to maintain the strike. ${ }^{88}$

More success was, however, achieved by the manufacturers on the following Monday, September 5 th. On the Sunday (after morning service!) the Bench had arranged measures for protecting workers who were willing to resume work. For their part the Chartists, including among their number John Wright, who was now released on bail, met at Bomber's Brow in the evening. With police and special constables in attendance, some mills proceeded to open their gates on Monday morning. Although most were soon obliged to close for want of hands, Messrs Bradshaw and Messrs Faulkner managed to continue work, at the pre-strike rates of pay. In spite of the presence of large crowds, a few of whom were arrested under the terms of the Improvement Act, for obstructing the footpath, these mills attracted a growing labour-force. Another Chartist, James Allinson, was arrested for trying to prevent one of Bradshaw's tenters from resuming work. ${ }^{89}$

\section{V}

In all the cotton towns of the district, Ashton, Stalybridge, Glossop, Dukinfield and Hyde, as well as Stockport, both operatives and mill-owners were still adamant at the beginning of September. ${ }^{90}$ However, even the most ardent of the turn-outs must by now have realized that a general return to work, at the pre-strike rates of pay, was only a matter of days

87 Ibid.

88 Ibid., 2 September.

89 Ibid., 9 September. James Allinson was subsequently sentenced to three months' detention in Knutsford House of Correction. It is not known whether he was related to John Allinson.

90 Lt. Col. Arbuthnot to Military Sec. Manchester, 3 September, HO 45/268. 
away. The sick and burial societies, last resorts for funds, were now becoming insolvent. ${ }^{91}$ By September $16 \mathrm{th}$, out of 35 cotton mills in the borough, 8 were in, or approaching, full work; 12 were partially at work, and 15 still closed. Many of the unemployed were, moreover, showing a desire to resume work. ${ }^{92}$ By September 23rd, all 35 mills had resumed work, and the strike in Stockport was at an end. ${ }^{93}$ With Stalybridge ${ }^{94}$ and Ashton ${ }^{95}$ strikers also back, there remained only the usual aftermath, the arrests. While the majority of Stockport inhabitants arrested during the course of the strike were in fact those involved in the attack on the workhouse, the local authorities were chiefly concerned with accumulating evidence against the Chartist leaders. ${ }^{96}$ Richard Pilling, whose arrest had been considered as early as 17 August, was finally apprehended at Charlestown, Ashton, on 5 September. ${ }^{97}$ James Mitchell was arrested at Churchtown, near Southport, where he had gone to deliver two lectures, ${ }^{98}$ while a message arrived from Hyde, asking for the assistance of the Stockport police in the capture of John Leach, who had absconded after a warrant had been issued. ${ }^{99}$ On 3 September the Government offered $£ 100$ reward for information leading to the arrest of Peter Murray McDouall. ${ }^{100}$ The major Chartist trial, that of O'Connor and 58 others, took place at Lancaster Assizes in March 1843. ${ }^{101}$

Thus the majority of Stockport operatives returned to work, at the pre-strike wage rates, and after weeks of increasing deprivation. The Chartists, some of whom had attempted to take over the strike against the

91 Stockport Advertiser, 16 September.

92 Ibid.

93 Ibid., 23 September.

94 Ibid., 16 September.

95 Northern Star, 24 September.

96 For example, see Mr Sadler's Minutes, SCP. Sadler lists meetings at which prominent local Chartists spoke. There is no record of speakers who advocated the "wages only" movement. See also Mr Beswick to Mr Sadler, Manchester, 21 August, SCP.

97 Magistrates' meeting, 17 August, SCP; Northern Star, 17 September.

98 Northern Star, 24 September.

99 Jos. Hibbert to Messrs Coppock \& Woollam, Solicitors, Hyde, 15 August; J. Little to J. Sadler, Chief Constable of Police, Stockport, Hyde, 21 August, SCP.

100 Placard issued by Sir Charles Shaw, Chief Commissioner of the Manchester Police,

Town Hall, Manchester, 3 September, SCP. McDouall is described as a surgeon, late of Ramsbottom, near Bury. He was "about 27 years of age, stands about $5 \mathrm{ft}$. 6in. high, inclined to be stout, has long dark hair, swarthy complexion, with high cheek bones, sharp black eyes, whiskers rather lighter than his hair; generally dresses in black; speaks quick, with a Scotch accent." Not surprisingly, he stood trial at the Lancaster Assizes.

101 The Trial of Feargus O'Connor, passim. Concerning the process by which evidence for the Crown was accumulated, see Tho. Part to Stockport Magistrates, Manchester, 5 September, SCP. 
wishes of their national leadership, and without the support of the majority of turn-outs, suffered more than any other group. Not only did they witness the imprisonment of their most prominent members, in some cases for the second time within four years, but they also faced the realization that they could no longer claim to form the leadership of the local working-class movement. Although Chartism survived in Stockport for another fifteen years, it never regained the hegemony which it had previously enjoyed.

The "Plug Plot" has often been regarded as a Chartist-inspired "General Strike". When, however, the documentary evidence for the Stockport area is examined in depth, this interpretation is shown to be far from accurate. There was no real "working-class solidarity", but a major division between the Chartists, who sought to utilize the strike for long-term political ends, and the "wages only" faction, which comprised a large number of cotton operatives and also gained the sympathy of a significant section of the town's lower middle class. While the extent of support for these two groups was always variable, being dependent upon the enthusiasms of mass meetings, clearly the "wages only" movement did hold greater appeal. How typical, within the wider area of the strike, was this sharp contrast in aims, and tendency to concentrate upon the wages question? The one obvious point of comparison, the Trades Conference in Manchester, indicates greater support for the Charter elsewhere. Unfortunately press reports of its proceedings failed to record the votes of individual delegates, or the extent of support which each delegate's point of view then enjoyed in his own locality. The indications are that Stockport's comparative lack of enthusiasm for the Charter was not typical of the cotton district in general, but only detailed studies of other areas can yield the necessary comparisons. What does, however, seem apparent is that in one of the oldest cotton towns, with a long tradition of working-class radicalism, the change in emphasis from political to industrial activity can be traced not, as has generally been accepted, from 1848, but from the "Plug Plot" of 1842. 